Rose-Marie Arbogast • Stefanie Jacomet •

Michel Magny $\cdot$ Jörg Schibler

\title{
The significance of climate fluctuations for lake level changes and shifts in subsistence economy during the late Neolithic (4300-2400 B.c.) in central Europe
}

Received: 1 April 2005 / Accepted: 16 December 2005 / Published online: 27 July 2006

(C) Springer-Verlag 2006

\begin{abstract}
In the last decades, data on the economy and environment of the Neolithic period of lake dwellings (4300-2400 в.C.) in central Europe has increased considerably and also palaeoecological data on lake level fluctuations has been thoroughly elaborated. Lake shores were mainly settled during warm and rather dry climate periods which caused a fall in the lake levels. Nevertheless, there were strong and partly very short-term shifts in the economy during the lake-dwelling period. These can be recognised only because the settlement layers can be very precisely dated by dendrochronology. In this article we discuss in an interdisciplinary way the possible interrelations between climatic and economic changes. To explain the latter, we assume crop failures as the main reason, which caused intensified hunting and gathering. There are three different possibilities which might explain this: cold and wet summers, severe droughts during spring and summer, or local over-exploitation of soils in densely settled areas.
\end{abstract}

Keywords Neolithic $\cdot$ Climate $\cdot$ Farming $\cdot$ Hunting . Lake level fluctuations $\cdot$ Central Europe

\footnotetext{
Communicated by Pim van der Knaap

R.-M. Arbogast · M. Magny

CNRS-UMR 6565, Université de Franche-Comté, Laboratoire de Chrono-Ecologie,

16 route de Gray,

25030 Besançon, France

e-mail: rosemarie.arbogast@unibas.ch

e-mail: michel.magny@univ-fcomte.fr

R.-M. Arbogast · S. Jacomet $(\bowtie) \cdot$ J. Schibler

Institute for Prehistory and Archaeological Science, Basel

University IPAS,

Spalenring 145,

4055 Basel, Switzerland

e-mail: stefanie.jacomet@unibas.ch

e-mail: joerg.schibler@unibas.ch
}

\section{Introduction}

Weather and climate significantly change the availability of energy and resources in agrarian societies, so that their scopes are enlarged or restricted. For example, the primary effects of an unusually wet and cold climate are diminishing yields of cultivated plants, domestic animals being in a poorer state, and higher mortality of humans and domestic animals, as we know from historical sources (Messerli et al. 2000; Pfister 2001).

For testing the possible influence of climate on early agricultural communities, it is necessary to have very dense and above all independent data about climatic variability and human activities. In many lakes in the surroundings of the Alps, the possibilities for the reconstruction of such interrelations during the Holocene are particularly favourable. Since the preservation of organic materials is very good in the waterlogged layers, much more information about the economy of prehistoric populations is available than from elsewhere (e.g. Jacomet et al. 2004). Furthermore, during the last 30 years, lake-dwelling archaeology has produced abundant results on the environment and economy during the Neolithic period (compiled in Jacomet 2004, 2006, in press; Schibler and Chaix 1995; Schibler 2004a; Schibler in press; Arbogast 1997, Fig. 1).

Widely different interpretations and conceptual models of the interrelations between humans and their environment have been published (e.g. Pétrequin 1997; Schibler et al. 1997a). In addition, in the past ca. 20 years lake level fluctuations and their relation to the climate have been reconstructed in detail (Magny 2004). It is also advantageous that in the area considered here (Switzerland, southern Germany, eastern France) the settlement phases are exactly dated by dendrochronology (Stöckli et al. 1995; Schibler et al. 1997a; Pétrequin 1997; Pétrequin et al. 2005, in press). Therefore, it is possible to correlate natural phenomena with human activities very precisely.

It is necessary for our aims to know exactly which climate parameters influence agricultural activities and to quantify 
Fig. 1 Geographical location of studied sites. A Sites with archaeobotanical data. 1: Lac de Chalain; 2: Lac de Clairvaux; 3: Yverdon; 4: Concise; 5 : Auvernier; 6: St. Blaise; 7: Twann; 8: Lüscherz; 9: Lattrigen (incl. Sutz); 10: Port; 11: Nidau; 12: Burgäschisee; 13: Egolzwil (Wauwiler Moos); 14: Risch; 15: Cham; 16: Zug; 17: Horgen; 18: Zürich (various settlements); 19: Pfäffikon (ZH); 20: Robenhausen; 21: Gachnang-Niederwil; 22: Thayngen-Weier; 23: Arbon-Bleiche 3; 24: Wangen; 25: Hornstaad; 26: Allensbach; 27: Bodman; 28: Sipplingen; 29: Wallhausen; 30: several sites in the region of Federsee/Oberschwaben (after Jacomet 2004). B Sites with archaeozoological data. 1: Lac de Chalain; 2: Lac de Clairvaux; 3: Yverdon; 4: Yvonand; 5: Portalban; 6: Muntelier; 7 : Auvernier; 8: St. Blaise; 9: Thielle; 10: Vinelz; 11: Lüscherz; 12: Lattrigen; 13: Sutz-Rütte; 14: Nidau; 15: Port; 16: La Neuveville; 17: Twann; 18: Burgäschisee; 19: Egolzwil (Wauwiler Moos); 20: Zug; 21: Horgen; 22: Zürich (various settlements); 23: Feldmeilen; 24: Meilen; 25: Pfäffikon ( $\mathrm{ZH}$ ); 26: Gachnang-Niederwil; 27: Arbon Bleiche 3; 28: Steckborn; 29: Hornstaad; 30: Sipplingen (after Schibler, in press)
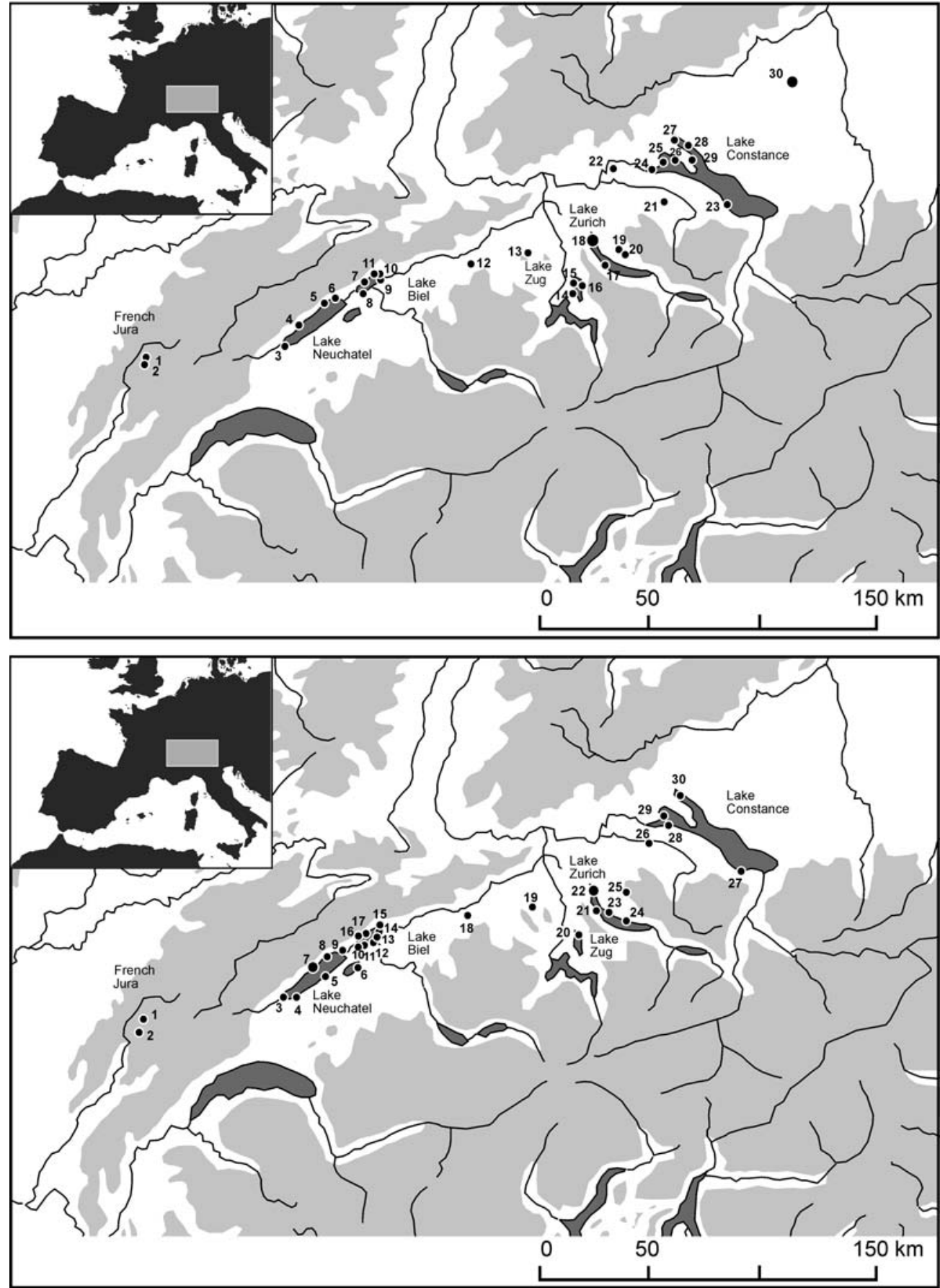

them. It has recently become more and more possible to calibrate biological and physical proxy data with the help of instrumental measurements and data from historical sources, from late medieval times onwards (see, for example, Pfister 1985, 2001; Pfister et al. 1999; Luterbacher et al. 2001). As a working hypothesis, such data can suggest possible mechanisms to explain the impacts of the climate on Neolithic farming societies. In this paper we summarise the results from a number of different disciplines and discuss the influence of climate and humans on economy and environment in the time span 4300-2400 B.c. Because the results and interpretations were produced in different countries (France, Germany and Switzerland) and on the basis of different scientific traditions, we use this opportunity to compare different interpretations and models. Many aspects of human life in the late Neolithic are still poorly understood, such as demography and social structures. These aspects are important because climate and society act together, and societies react differently and have different sensibilities to climatic impact. The effects of bad years and catastrophic events depend on the load capacity of the economy and society, the density and location of the settlements, and the carrying capacity of the social network (Pfister 2001). 


\section{Material and methods}

Changes in regional lake levels and climatic development

In addition to proxy data obtained from ice sheets and oceanic sediments, lake level studies have provided relevant data for palaeoclimatic reconstructions in the continental areas and especially in Europe (Gaillard 1985; Digerfeldt 1988; Magny 1992; Harrisson and Digerfeldt 1993; Harrisson et al. 1996; Digerfeldt et al. 2000). Lake level data also supply information for modelling experiments and can be used to refine palaeoclimatic reconstructions based on pollen data (Guiot et al. 1993; Magny et al. 2001, 2003, 2005). In particular, lake level records give specific information on precipitation changes, in contrast to most climatic markers documenting often only temperature changes. Fluctuations of lake levels can result from various local non-climatic factors, but regionally synchronous fluctuations can be assumed to be climatically driven (Harrisson and Digerfeldt 1993).

Over the last 20 years, systematic investigations on Holocene lake level changes have been carried out in the Jura mountains, the northern French pre-Alps, and the Swiss Plateau (Fig. 1). Past lake level fluctuations have been reconstructed according to Magny $(1992,1998)$ on the basis of three parameters:

1. Modern analogues, by comparing the sediment record with the types of deposits accumulating today in the lakes in the Jura and subalpine area (different morphotypes of carbonate concretions, the frequency of which varies in relation with the water depth and the aquatic vegetation belts).

2. A combination of parameters such as texture (grain size) and lithology (peat, carbonate lake-marl, gyttja).

3 . The geometry of the sediment layers, which can show erosion surfaces due to a lowering of the lake level and consequently of the sediment limit (Digerfeldt 1988).

Finally, given the high sedimentation rate which characterizes the lake-shore areas, a contiguous high-resolution subsampling of sediment sequences made the identification of short-term events possible.

Lake level changes were dated by radiocarbon dating of peat, detritus peat and terrestrial macrofossils and by treerings in wooden posts of Neolithic dwellings. The lakes studied are small basins characterised by a common nivopluvial regime with a lake level minimum during summer and maxima during rainy seasons and snow melt (autumn and spring). They exhibit a great sensitivity to variations in water supply as shown by seasonal changes in water level, and can be considered to react quasi-instantaneously to meteorological and climatic events.

\section{Environment and plant economy}

In the past 30 years many off-site pollen diagrams have yielded abundant data on the environment during the late
Neolithic (e.g. Ammann et al. 1981; Richoz and Haas 1995; Rösch 1990, 1993; Liese-Kleiber 1993; Hadorn 1994; Beckmann 2004). Some diagrams were very closely sampled and therefore allow the reconstruction of short-term changes. The dating is mainly based on AMS ${ }^{14} \mathrm{C}$ dates from macrofossils and on dendrochronology in settlement areas.

Furthermore, we have plenty of relatively detailed knowledge of the near surroundings of the Neolithic settlements from on-site (mainly macroremain) data (e.g. Brombacher and Jacomet 1997; Jacomet et al. 1989; Mermod 2000; Hosch and Jacomet 2004; Maier 2001; Lundström-Baudais 1986). Several thousand samples have been investigated from more than 80 settlements (Fig. 1; Jacomet 2004, 2006 , in press; Jacomet and Brombacher 2005). However, there are almost no interdisciplinary studies combining off-site and on-site data (see below).

Our knowledge of the plant economy is based on on-site studies (Fig. 1). However, very few settlements are investigated in a representative way and the methods applied have been heterogeneous, so a standardised quantification is not possible (Jacomet and Brombacher 2005). Two examples may exemplify this: uncarbonised cereal chaff is widespread in organic settlement layers, but it is largely destroyed when sieving is done in an inappropriate way (Hosch and Zibulski 2003). The more stable hazelnut shells pose another problem. They are found in large amounts, but the shells are broken into pieces of very different sizes. Depending on the method of counting, very different densities arise. Larger-seeded fruits are underrepresented in the small samples of less than a litre, on which the larger part of our results is based (Jacomet and Brombacher 2005).

\section{Animal husbandry and hunting}

Our knowledge for the period between 4300 and 2400 B.C. is based on more than 300,000 identified hand-collected animal bones from over 150 settlement phases (Fig. 1; Hüster-Plogmann et al 1999; Schibler and Hüster Plogmann 1995; Schibler and Jacomet 1999; Schibler and Steppan 1999; Arbogast 1997). The western part of the Pre-Alps (Alpenvorland) has provided archaeozoological results from 52 settlements, the eastern part 74 (Schibler, in press), and the French Jura 25. We do not consider small animals like fish or amphibians, because they were studied in only few settlements. Exceptions are Chalain 3 (Pétrequin 1997) and Arbon Bleiche 3 (Hüster-Plogmann 2004).

Most settlements with archaeozoological results are dated by dendrochronology or AMS ${ }^{14} \mathrm{C}$ dates with a precision of a few years to at most a few decades. Settlements dated with a $<50$ years precision were excluded. To evaluate the importance of hunting and husbandry we used primarily the proportions (percentages) of fragment numbers of identifiable bones, since only this type of quantification is available for all sites (Schibler, in press). However, it does not show whether changes in the relationship between wild and domestic animals are due to intensification of hunting or of husbandry, collapse of husbandry, or a combination 
of both. To overcome this problem, we used "find densities" of the two categories of bones, which is the number of bones per square metre and settlement phase in 10 year phases for each village with sufficient data (Schibler et al. 1997a; Schibler 1997a,b; Arbogast et al. 1995; Pétrequin et al. 1998). This is only the case in the Zürich region and for most of the layers of the French Jura lakes like Chalain and Clairvaux (Fig. 1). Because preservation conditions are not comparable between regions, relative changes are judged rather than densities.

We use Logarithmic Size Indices (LSI) (Uerpmann 1979, 1990; Payne and Bull 1988; Meadow 1999) for the comparison of the biometrical data, which allows us to compare relative sizes or proportions of red deer and cattle in time slices of at most one century. For the Swiss Pre-Alps we can only use data from the eastern part, because the osteological measurements of other larger datasets are not yet published or are not subdivided into shorter time slices or layers.

\section{Historical data}

A large amount of historical weather data for central Europe has recently been collected by C. Pfister (Bern University) and several other historians (Pfister 1985). It is therefore very possible to estimate the scale of the climatic fluctuations of the past ca. 500 years and their influences on the yields of cultivated plants (see, for example Pfister 1985, 2001; Pfister et al. 1999; Luterbacher et al. 2001). The great advantage of this data is that biological and physical proxy data (like the changes in the lake levels mentioned above) can be calibrated with the help of historical source data (Pfister 2001). The last 500 years are characterised by a very strong negative climate anomaly, the so-called "Little Ice Age" (see, for example, Luterbacher et al. 2001). It is therefore mostly possible to quantify the effects of unusually cold and wet summer periods on the crop yields. However, there is also some data about unusually dry periods (such as the summer of 1540; Gläser et al. 1999).

\section{Results}

Lake levels and climate history based on proxy data

Regional lake level fluctuations in the period 4500-2000 B.C. in 13 lakes have already been published (Magny 2004). Fig. 2 presents lake level records from Morat and Constance (Bodensee) on the Swiss Plateau and Clairvaux and Chalain in the French Jura mountains (Magny 1992; Haas and Magny 2004; Magny and Haas 2004; Magny in press; Magny et al. 2005, 2006). These lake level records document in more detail distinct time windows. The regional lake level fluctuations show higher water tables at ca 44004150, 4000-3950, 3700-3250, 2900-2850, 2600-2450 and 2200-2000 в.C. The phase 3700-3250 в.c. is composed of three successive events centred on ca 3600, 3500 and 3350 B.C. (Magny et al. 2005). Moreover, the records from Lac de Chalain highlight a minor phase of higher lake level at ca 2600-2400 B.C.

Fig. 2 shows possible correlations between midEuropean lake level fluctuations and variations (1) in timberline at Rotmoos in the Austrian Alps (Bortenschlager 1970) and (2) the atmospheric ${ }^{14} \mathrm{C}$ content based on treering data (Stuiver et al. 1998). Rotmoos is an Alpine mire at $2300 \mathrm{~m}$ a.s.l. where Bortenschlager (1970) defined the midHolocene cooling events Rotmoos 1 and 2 on the basis of an altitudinal decline of the timberline (maximum of NAP). The matching of the Rotmoos record with the ${ }^{14} \mathrm{C}$ record was constrained by calibrated radiocarbon ages (within 1 sigma range and using IntCal 4.3; Stuiver et al. 1998) obtained by Bortenschlager (1970). The ${ }^{14} \mathrm{C}$ record may be considered as a proxy for past changes in solar activity. Similarities between the ${ }^{14} \mathrm{C}$ and ${ }^{10} \mathrm{Be}$ records suggest that variations in these isotopes are primarily driven by changes in production and reflect strong influences of variations in solar activity (Muscheler et al. 2000; Beer 2000; Renssen et al. 2000).

Possible correlations between mid-European lake levels, Alpine timberlines and atmospheric ${ }^{14} \mathrm{C}$ records as illustrated by Fig. 2 suggest a marked mid-Holocene climatic and environmental variability in response to changes in solar activity (Magny 2004), which is in agreement with other palaeoclimatic and palaeoenvironmental studies (Bond et al. 2001; Blaauw et al. 2004; Chambers et al. 1999). Moreover, the period 3700-3200 B.C., taken as a whole, appears to have been a long-lived climatic reversal. This major mid-Holocene climatic event marks the Hypsithermal-Neoglaciation transition (Steig 1999) and coincided with a major lowering of the tree-line in the Swiss Alps (Tinner and Theurillat 2003). Possible correlative events have been observed in both hemispheres (Magny and Haas 2004; Mayewski et al. 2004).

As an example in the perspective of the following discussion, Fig. 3 presents pollen and lake level based estimates of climatic variables reconstructed at Montilier (Lac de Morat; see Fig. 1) for 4600-3500 B.C., using the best analogue method (Guiot et al. 1993). In general, the phases of lower lake levels coincide with increased mean temperature of the warmest month (MTWA), growing days above $5{ }^{\circ} \mathrm{C}$ (GDD5) and decreased annual precipitation (PANN). The phases of higher lake levels correspond to the opposite processes. The changes reached a magnitude of $2{ }^{\circ} \mathrm{C}$ for MTWA, $1.5^{\circ} \mathrm{C}$ for mean annual temperature (TANN) and 100/150 $\mathrm{mm}$ for annual precipitation (PANN). However, no clear centennial oscillation can be recognised in mean temperature of the coldest month (MTCO). This suggests a greater contribution of the summer than the winter to mid-Holocene climatic variations, which agrees with observations and experiments by Bortenschlager (1977), who concluded that a tree-limit lowering was caused not by severe winters but chiefly by a lowering of mean temperature during the growing season, and consequently its shortening. This is in agreement with the GDD5 estimates reconstructed at Montilier. MTWA fluctuations with a $2{ }^{\circ} \mathrm{C}$ amplitude at Montilier are also consistent with reconstructions by Patzelt (1977) and Zoller (1977) in the Austrian 


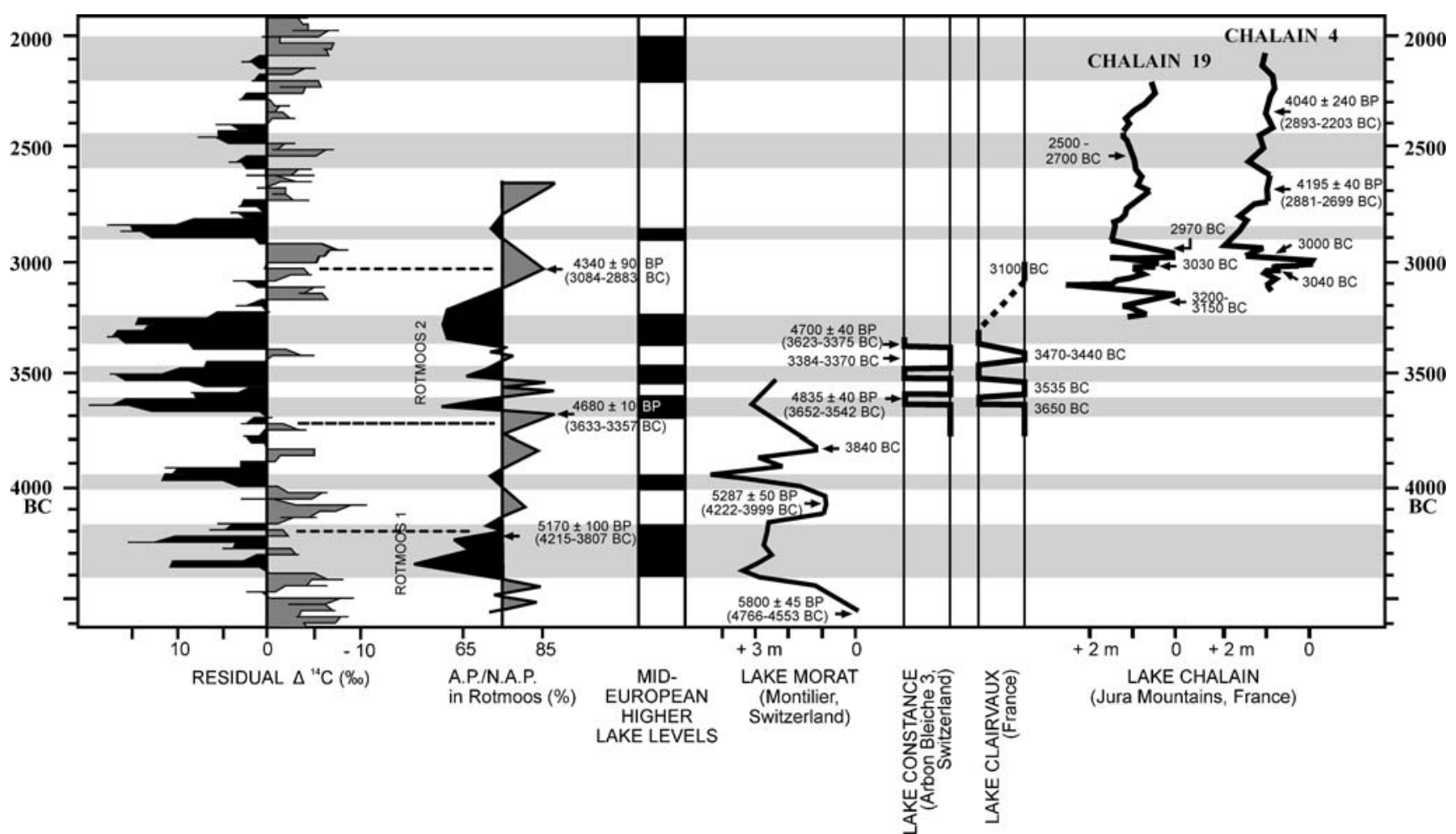

Fig. 2 Comparison between (1) variations in the atmospheric ${ }^{14} \mathrm{C}$ content (Stuiver et al. 1998), (2) tree-limit fluctuations reconstructed at Rotmoos in the Austrian Alps (Bortenschlager 1970), and (3) the mid-European lake level record established from 13 lakes in the Jura mountains, the northern French Pre-Alps and the Swiss Plateau (from Magny 2004), and details of lake level records from Lac de Morat

and Swiss Alps from changes in tree-limit $\left(1.5^{\circ} \mathrm{C}\right)$. Assuming that the oxygen isotope variations reflect changes in TANN with a slope of $0.58 \pm 1 \%{ }^{\circ} \mathrm{C}$ (von Grafenstein et al. 1998), the Ammersee record in south Germany suggests mid-Holocene variations in TANN reaching $1.5 / 1.7{ }^{\circ} \mathrm{C}$, close to the values obtained at Montilier $\left(1.5^{\circ} \mathrm{C}\right)$. However, in the Swiss Alps at ca. 6000 cal B.P., chironomid-based estimates suggest a decrease in summer temperature of less than $1{ }^{\circ} \mathrm{C}$ for a cooling event synchronous with a tree-limit decline (Heiri et al. 2003, 2004). Further investigations using distinct proxies are necessary to document more extensively and in more detail the second half of the Holocene period and to provide a more precise picture of temperature and precipitation changes in western central Europe. Multi proxy approaches (Haas et al. 1998) and high resolution tree-ring studies (Schmidt and Gruhle 2003) could offer relevant proxies in this perspective.

To sum up, the time window considered for this study was characterised by a marked climatic instability. The magnitude of temperature changes could have reached 1$2{ }^{\circ} \mathrm{C}$ for MTWA and $1.5^{\circ} \mathrm{C}$ for TANN. The growing season seems to have been more affected than the winter season.

Evaluation of historical sources and calibration of proxies

The well-documented "Little Ice Age" (LIA), especially the Late Maunder Minimum (LMM, A.D. 1645-1715) which is
(Magny et al. 2005), Lake Constance (Bodensee) (Haas and Magny 2004), Chalain (Magny in press) and Clairvaux (Magny 1992, 1993a). Grey bands mark regional phases of higher lake levels as defined in Magny (2004). Calibrated ages ( $1 \sigma$ time window) were calculated using IntCal 4.3 (Stuiver et al. 1998)

the coldest phase of the LIA (e.g. Luterbacher et al. 2001), offers the opportunity to observe the variability of the climate during a late Holocene cooling phase. This period coincides with an enhanced concentration in atmospheric ${ }^{14} \mathrm{C}$, several large volcanic eruptions, reduced solar activity, and a low number of sun spots (Luterbacher et al. 2001). During the LMM (1645-1715) there was a decrease in the northern hemisphere $(\mathrm{NH})$ April-September temperatures in the order of $0.3-0.6^{\circ} \mathrm{C}$ compared to the reference period of 1961-1990. The LMM is one of the few cold periods in recent centuries that persisted for decades. A broad spectrum of high-resolution multi-proxy and instrumental data is available for this period (Luterbacher et al. 2001).

The springs in central and eastern Europe during the LMM from 1687-1717 were the coldest in the last 500 years, with a partial decrease of $2{ }^{\circ} \mathrm{C}$ in mean temperature compared to the reference period of 1901-1960. The NH summers from 1691-1700 were the coldest of the last millennium. In Switzerland, from 1695-1705, no single summer was warm and dry. The worst summer was 1692, which led to famine in many parts of France, Switzerland and Germany. In Scotland, for example, the harvests [mostly Avena sativa (oats)] failed in seven out of eight years between 1693 and 1700, causing mass emigration. These LMM long-lasting climatic anomalies must have had their origins in a marked change of the atmospheric circulation (Luterbacher et al. 2001). They show strong similarities to the variations in climatic parameters 
Fig. 3 Quantitative reconstruction of climatic variables from the sediment sequence of Montilier, Lac de Morat (Swiss Plateau) using pollen and lake-level data (from Magny et al. 2005). MTWA, mean temperature of the warmest month; MTCO, mean temperature of the coldest month; TANN, mean annual temperature; GDD5, growing degrees above $5{ }^{\circ} \mathrm{C}$ x days; PANN, annual precipitation
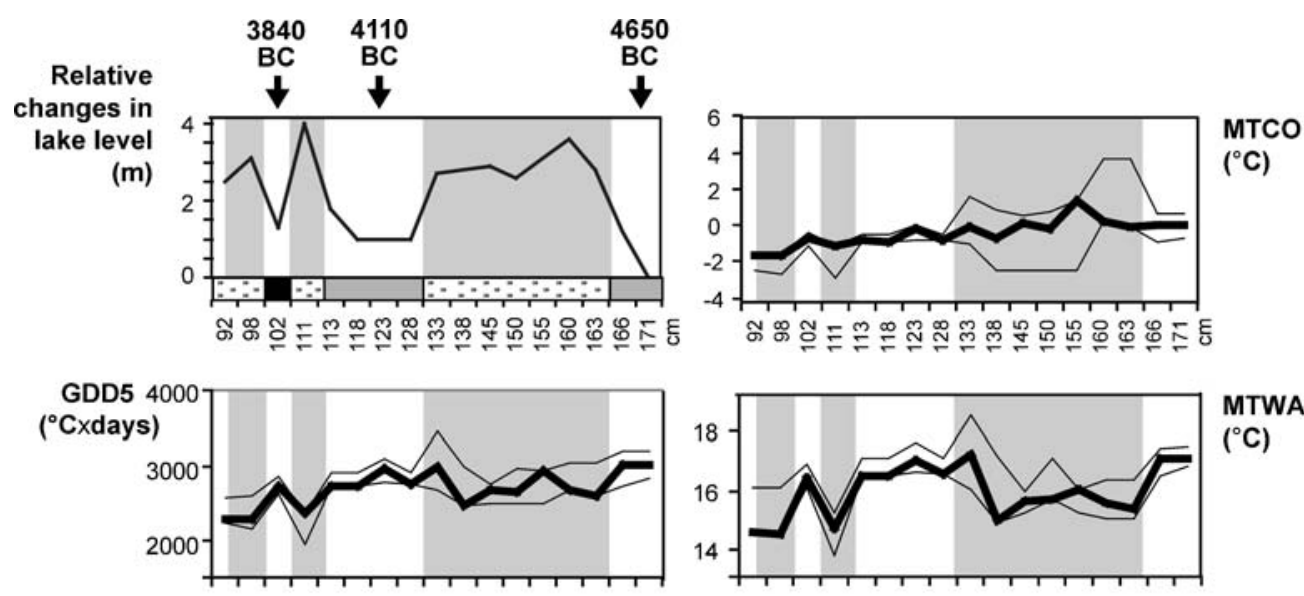

MTWA $\left({ }^{\circ} \mathrm{C}\right)$
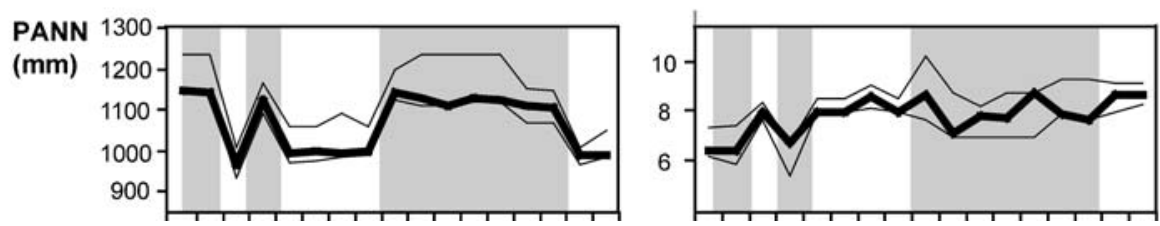

TANN ( $\left.{ }^{\circ} \mathrm{C}\right)$ as reconstructed from pollen and lake level data for the Neolithic period (Magny et al. 2005, Fig. 3).

It is also possible to quantify the effects of unusually cold and wet summers on the yields. These led, for example, to a harvest which was around 3-4 weeks later than usual (Pfister 2001). The descriptions of two very cold and wet years (1573 and 1587) may serve as examples (Gläser et al. 1999). In both years, the winter was very long lasting, large lakes were also frozen and even many game animals in the forests died. The cold continued during the whole springtime. Cold and rainy weather continued for the whole summer in 1573, causing the grain and grape harvests to totally fail. In Switzerland, from early September to early October 1573 it rained almost continuously, and many rivers overflowed their banks.

The heat and drought in 1540 may serve as an example of a contrast scenario (Gläser et al. 1999 and C. Pfister, personal communication). This year was the driest and warmest such period known from the documentary data of central Europe. In Switzerland, rain fell only three to four times from April to June. At the end of May the grass on the Swiss Plateau dried out completely. In July, no rain fell in the lowlands. Cattle died from starvation, grapes dropped off the vines, fruit and leaves fell from the trees and many forests caught fire. Many small rivers dried out completely, and even the level of the Rhine was so low that it could be walked across at several locations, while many fish died.

As shown from these sources, the palette of weather combinations which were responsible for lower crop yields and ill health in domestic animals can be many. On the one hand, wet September and October, early onset of winter, cold March and April and a very wet midsummer are responsible for problems in agricultural production (Pfister 2001). In addition, the low-grade cereals were more likely to go mouldy. On the other hand, severe droughts could also have had a negative impact on husbandry, however, not so much on winter cereals. Finally, "bad weather" also seriously affected humans, because epidemics could cause higher mortality (Pfister 2001). Malnourished people were more likely to become victims of infectious diseases.

\section{Settlement history}

As shown in Fig. 4, the settlement history of the circumAlpine lakes during the Neolithic (4300-2400 B.C.) is on the one hand characterised by periods with a dense settlement of the lake shores and other wet places. On the other hand, there are phases with only a few sites or even a lack of settlements. Based on the research carried out up to now it becomes obvious that the settlement phases of most of the lakes are to a greater extent contemporary (Fig. 4). Furthermore, the time slices characterised by peaks in the frequency of lake-dwellings generally coincide with low lake levels and weak concentrations of atmospheric ${ }^{14} \mathrm{C}$ (Figs. 2 and 4; Magny 1993c, 2004, in press; Pétrequin et al. 2005; Gross-Klee and Maise 1997). In contrast, periods with higher lake levels correspond in most cases to abandonment periods and to periods with a wet climate. People left the zones of the lake shores where remains could be preserved. There are however several examples where a settlement lasted for a few years at the beginning of such wet periods, as in the case of Arbon Bleiche 3 (Haas and Magny 2004). Other examples we know from the period 3700-3600 B.C. where several settlements continued although a cold, but initially obviously dry phase had begun, for example Zürich Mozartstrasse, layer 4, 3660 to 3600 B.C. (Schibler and Steppan 1999). More generally, Fig. 4 shows a relative persistence of lake-dwellings until 3600 B.C. This suggests progressive changes in climate conditions and/or possible capacities of past societies to adapt their architectural techniques to a changing environment. 


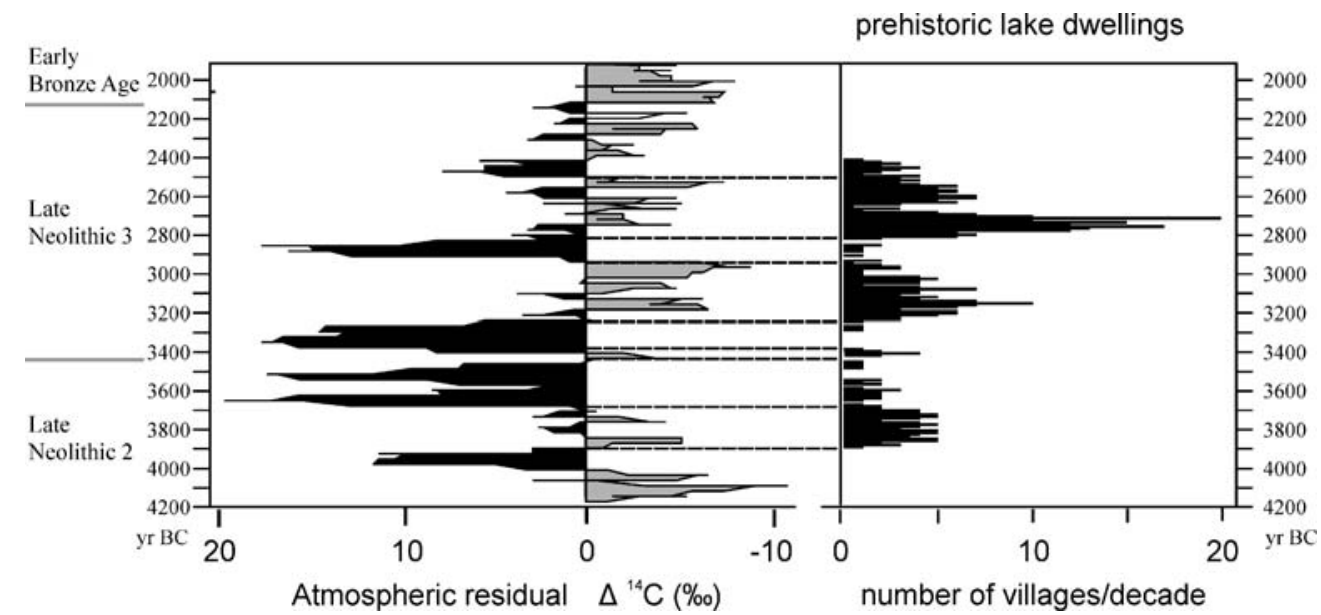

Fig. 4 Comparison between the fluctuations of the atmospheric residual ${ }^{14} \mathrm{C}$ (from Stuiver et al. 1998) and the number of villages per decade on the lake shores during the Neolithic and the Bronze Age in eastern France and on the Swiss Plateau (from Magny 1993b, c). Late Neolithic 2 is in the French terminology "Néolithique Moyen"

The observed fluctuations of settlement density are the reason why our knowledge of the economy is discontinuous. It is based on remains from the occupation phases. But there are phases when almost no settlements existed on the lake shores or when they were eroded (Fig. 4). Partly, people must have moved away from the lake shores, but our knowledge of settlement activities in the hinterland zones is very patchy (almost no excavations, few prospecting activities). Therefore, the two main periods of unfavourable (mostly wet; see above) climate, between ca. 3550 and 3250 B.C. and around 2900 B.C. correspond to periods from which our knowledge is very fragmentary. We know very little about the metrical traits of the animals, the economy and the social system during such periods, data which are normally used to reconstruct adaptations to unfavourable climatic conditions.

\section{Environment and plant economy}

In the area concerned here (Fig. 1), the environment in Neolithic times was dominated by a wooded landscape. With the onset of lakeshore settlement around 4300 B.C. the Quercetum Mixtum (QM) (mixed oak woodland) did not play a dominant role any more. Fagus (beech) was very important, in large parts of the area accompanied by Abies alba (fir). Other trees such as Quercus (oak) or Fraxinus (ash) and others remained only locally important (for the western Swiss Plateau, see Ammann 1989; Richoz and Haas 1995; for the Lake Constance (Bodensee) region, see cited publications of M. Rösch). Evidence of human impact in off-site pollen cores is astonishingly very weak (see Richoz and Haas 1995; Rösch 1992). This suggests that the hinterland was totally (or at least to a high degree) forested.

However, according to pollen results in the Lake Constance region, people and their domestic animals (mainly and in the German terminology "Jungneolithikum". Late Neolithic 3 is, in the French terminology, "Néolithique récent et final" and in the German terminology "Spät- und Endneolithikum" (Jacomet in press). Phases of lower lake levels and prehistoric lake-dwellings are marked with dotted lines

cattle, but also small ruminants) in the late Neolithic transformed larger parts of the woodlands into a landscape dominated by coppiced woods and bushes, partly with the help of fire (Rösch 1997, 2000). This fits very well with written sources about native North American Indians in the eastern woodlands in the 18th century (Hammett 1997). These groups maintained with the help of various "management practices" a sort of park landscape which served as an "orchard", a place for hunting and a wood reservoir. However, we do not have very exact ideas about the extent of this strongly influenced Neolithic landscape. For this, it would be necessary to make a model based on the calorie requirement of the population, including the feeding of the domestic animals (e.g. Flannery 1986). In the lakedwelling area this was performed only sporadically (as for one settlement in the Zürich area by Gross et al. 1990).

The very near surroundings of the settlements were obviously much more strongly influenced (Jacomet et al. 2004, synthesis). Here people cultivated fields and at least parts of the animal herd also browsed around there. This territory was most probably within a radius of $1 \mathrm{~km}$ around the settlements.

The plant economy of the late Neolithic lake-dwellings was rather heavily based on domesticates (Jacomet 2004, 2006, in press; Jacomet and Brombacher 2005). Among the cereals, Triticum durum/turgidum (tetraploid naked wheat), T. dicoccum (emmer), T. monococcum (einkorn) locally (mainly in western Switzerland) and finally Hordeum vulgare (six-rowed barley) were most important. Their remains, including whole ears (e.g. Maier 1996), appear in large amounts in the settlements. There are some shifts in the importance of mainly the wheat species in the region concerned (see Jacomet 2006, in press). In the second half of the 4th millennium B.C. the prevailing tetraploid naked wheat was gradually replaced by emmer. There are also other, more short-term shifts in the proportions of the various cereals. However, an interpretation of such facts 
is not possible because of methodological inconsistencies and because the varieties grown are not known, or are at least not directly comparable with modern varieties. If the shifts in crops being grown were due to climatic factors, soil overexploitation or to cultural change, as with the onset of the Horgen culture in the middle of the 4th millennium B.C. with strong easterly influences, is not clear at all.

As far as ears are found, one can conclude that the varieties used were very fruitful, and they seem to have been very well grown. A recent study of weeds with the help of the FIBS method (Functional Interpretation of Botanical Surveys) suggests that during Neolithic times most of the cereals were sown as winter crops and planted on small-scale, garden-like plots which were intensely cultivated (Bogaard 2004). FIBS is based on the observation of plant ecologists that species sharing the same habitat also tend to share ecological and morphological characteristics and thus belong to a distinct "functional type". The method links characteristics of the species rather than species per se with particular traditional crop husbandry practices.

Other important cultivated plants were Linum usitatissimum (flax, linseed) and Papaver somniferum (opium poppy) which also show shifts in their importance. There was also some growing of Pisum sativum (pea). All three were supposedly sown as summer crops.

Based on the usual findings-among the cereals chaff remains and single grains or cereal bran-it is highly hypothetical to quantify the remains (Jacomet and Brombacher 2005). Nevertheless, attempts to reconstruct the ratio of the cultivated plants (Jacomet and Schibler 1985; Hosch and Jacomet 2004) pointed to the very great importance of the cereals, followed by linseed. Therefore, we have to suppose that a worsening climate, in the case of cereals mainly wet and cold conditions, could seriously affect the supply of cultivated staple foods.

Beside cereals, gathered plants played an important role in food supplies. The most important calorie rich and storable foods are Corylus (hazelnuts), Quercus (acorns), Fagus (beech-nuts) and Malus (crab-apple). In addition, many berries were collected, but it is not known if they were only eaten fresh or also stored. Most of the small heaps of remains of these found in the layers are interpreted as excrement, see for example Maier (2001). There were most probably other plants or plant parts which were collected and eaten, like roots, tubers, stalks, mushrooms etc., but are only very rarely traced in the they are not (or only very rarely) traceable in the archaeobotanical record.

Attempts to reconstruct the ratio of the domesticated versus the gathered plants (Jacomet and Schibler 1985; Gross et al. 1990; Hosch and Jacomet 2004) point to the fact that the domesticated plants played a more important role in the food supply. However, a considerable part of the calories from plant foods, at least $1 / 3$, must have been gained by collecting. But archaeobotany can yield only very few good examples of a greater importance of gathered plants or a lesser importance of cereals. Perhaps the best example of a greater importance of gathered plants, especially the fatrich hazelnuts, comes from the site of Hornstaad-Hörnle IA (Maier 2001). This settlement burned down some years after it was built (3917 B.C.), and this took place very soon after the harvest. The whole burnt layer was full of still unthreshed cereal ears. The settlement was rebuilt after this catastrophic event and in the layer directly above, a stratum very rich in hazelnut shells was observed. This shows that people tried to compensate for the burning of the harvest with an increased effort in collecting hazelnuts. However, this probably had nothing to do with climate. But one could conclude that people would do the same when the cereal yields were reduced by climatic impact. Some indications for such a situation, although very hypothetical, we found at the site of Zürich Mozartstrasse, layer 4 (Schibler et al. 1997a, 1997b).

\section{Animal husbandry and hunting}

\section{Variability in meat consumption}

The economically most important domestic animals during the Neolithic in the circum-Alpine area were cattle, sheep, goat and pig. The most important hunted animal in all regions considered here was Cervus elaphus (red deer) (Schibler and Chaix 1995).

For the Pre-Alps and the French Jura lakes region, different phases of occupation showing a high importance of game can be recognized (Figs. 5 and 6). Especially high proportions of wild animal bones (between 40 and $80 \%$ of the bone fragments) can be recognized in the settlements at 4200-4050, 4000-3800, 3700-3600, 3400-3300, 3150 3000 and 2900-2700 B.C. in most regions of the Swiss Pre-Alps, and between 3100 and 2950 B.C. in the villages of the French Jura lakes region.

For many layers (before 3600 B.c.) where find "densities" could be evaluated, we can observe that high percentages of wild animal bones correspond with higher find "densities" of these (Fig. 5). On the other hand, during these periods of higher percentages and higher find "densities" of wild animals, we see only minor fluctuations of the find "densities" of domestic animals.

This gives the impression of an animal husbandry which was more or less stable and where hunting was the only part of the meat procurement which was flexible. Therefore, during phases of higher find "densities" of wild animal bones (mostly red deer bones) more meat was being procured and consumed.

\section{Variability of the biometrical results}

If we look at the box plots of the LSI (Logarithmic Size Indices) values grouped in time slices of one century for the red deer bones of the settlements of the eastern part of the Swiss Pre-Alps, we recognize a broad fluctuation (Fig. 7a). Especially small values can be recognized around 3800 , 3700 and 2800 B.C. A fluctuation of the LSI values was also observed in the French Jura lake settlements (Fig. 7b): at first sight the differences here seem to be regional; the values for Lac de Chalain are in general lower than those 


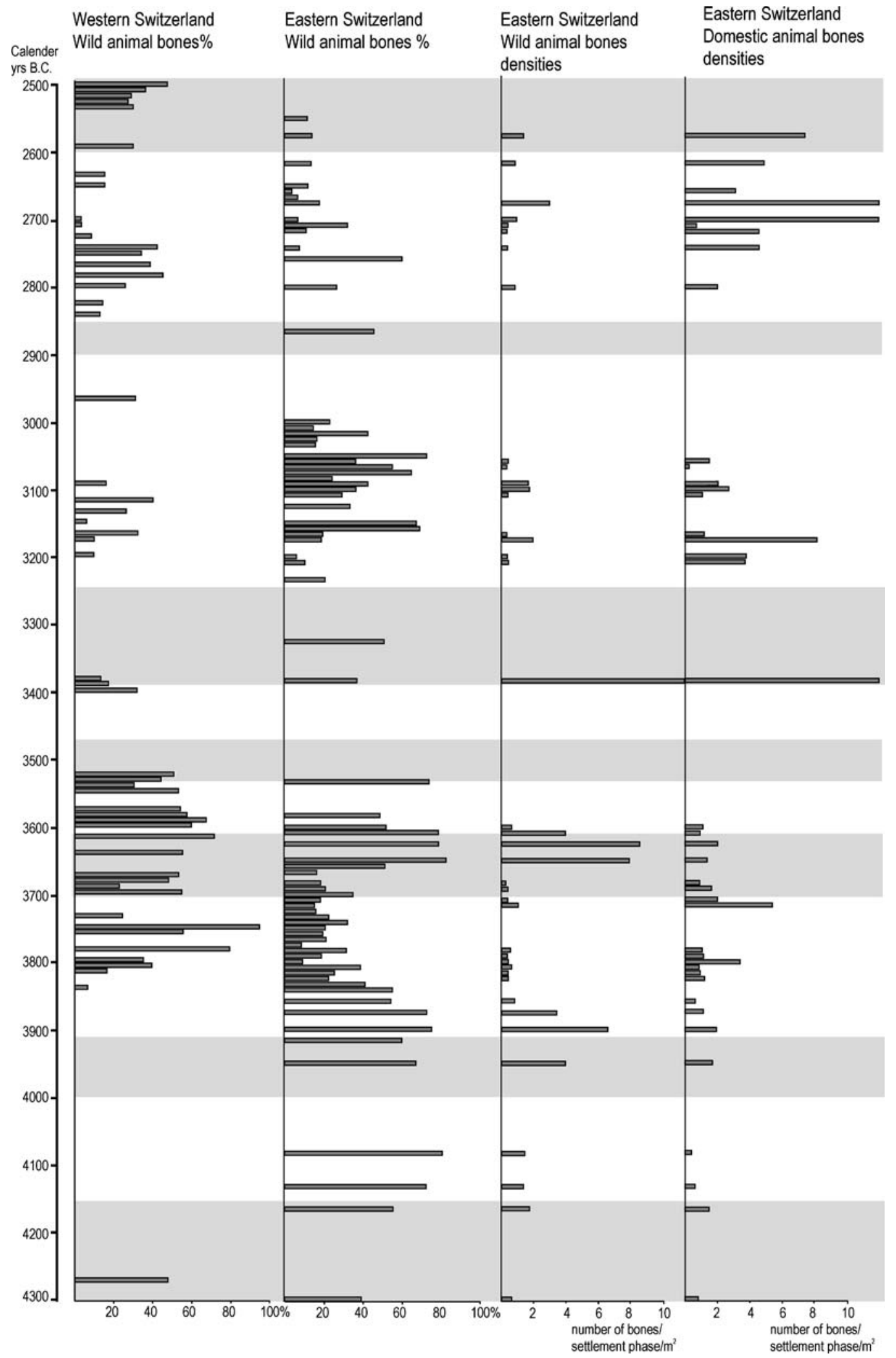

Fig. 5 Fluctuations of the proportions of domestic and wild animals in the Neolithic lake dwellings on the Swiss plateau. Percentages of the identifiable bones and "densities" per settlement phase and square metre. A calculation of "densities" for the settlements in western Switzerland is not possible (after Schibler in press). In grey, phases with unfavourable (mostly wet) climate conditions (after Fig. 2) 
Fig. 6 Fluctuations of the proportions of domestic and wild animals in the Neolithic lake dwellings in the French Jura lakes Chalain $(\mathrm{CH})$ and Clairvaux (CL). Example of reading: CH 3 VIII: Chalain, station 3, layer VIII. MM: settlement Motte aux Magnins with layers A-C. Percentages of the identifiable bones and

"densities" per 10 years of a settlement phase and $\mathrm{m}^{2}$. From Pétrequin et al. (1998)
Fig. 7 LSI values of red deer bones in the Neolithic lakeshore settlements mentioned: A values from the Zürich area. After Hüster-Plogmann and Schibler 1997. B Values from the lakes Chalain and Clairvaux in the French Jura (Arbogast unpubl.). In grey, phases with unfavourable climate conditions (after Fig. 2). The LSI values are based on the red deer reference skeleton (no 2271) in the bone collection of the IPAS of Basel University.

Explanations to LSI are in the text. The period 3200-3120 B.C. includes the settlements Chalain 3 VIII et VI, 3040-3020 B.C. the settlements Chalain 4-1, 4-2 and 4-3, 3000-2980 B.C. the settlement Chalain 4-4, 2980-2940 в.c. the settlements Clairvaux MM (Motte aux Magnins) layers A, B and C, 2750-2700 B.C. the settlements Clairvaux MM (Motte aux Magnins) layers $\mathrm{F}$ and $\mathrm{G}$ and 2650-2600 B.C. the settlement Clairvaux MM (Motte aux Magnins) layer K
Calendar Sites and yrs B.C. layers
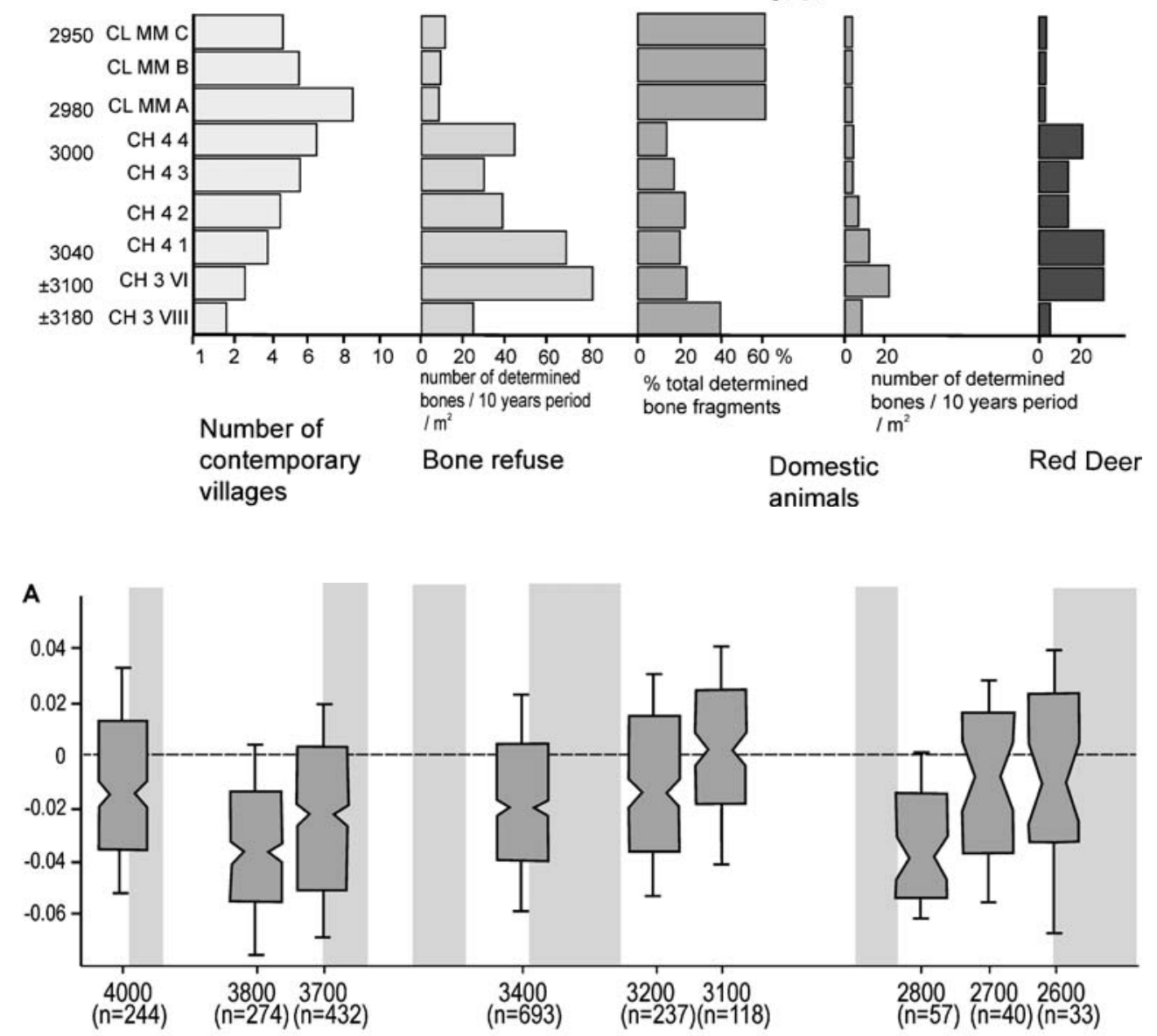

B Chalain

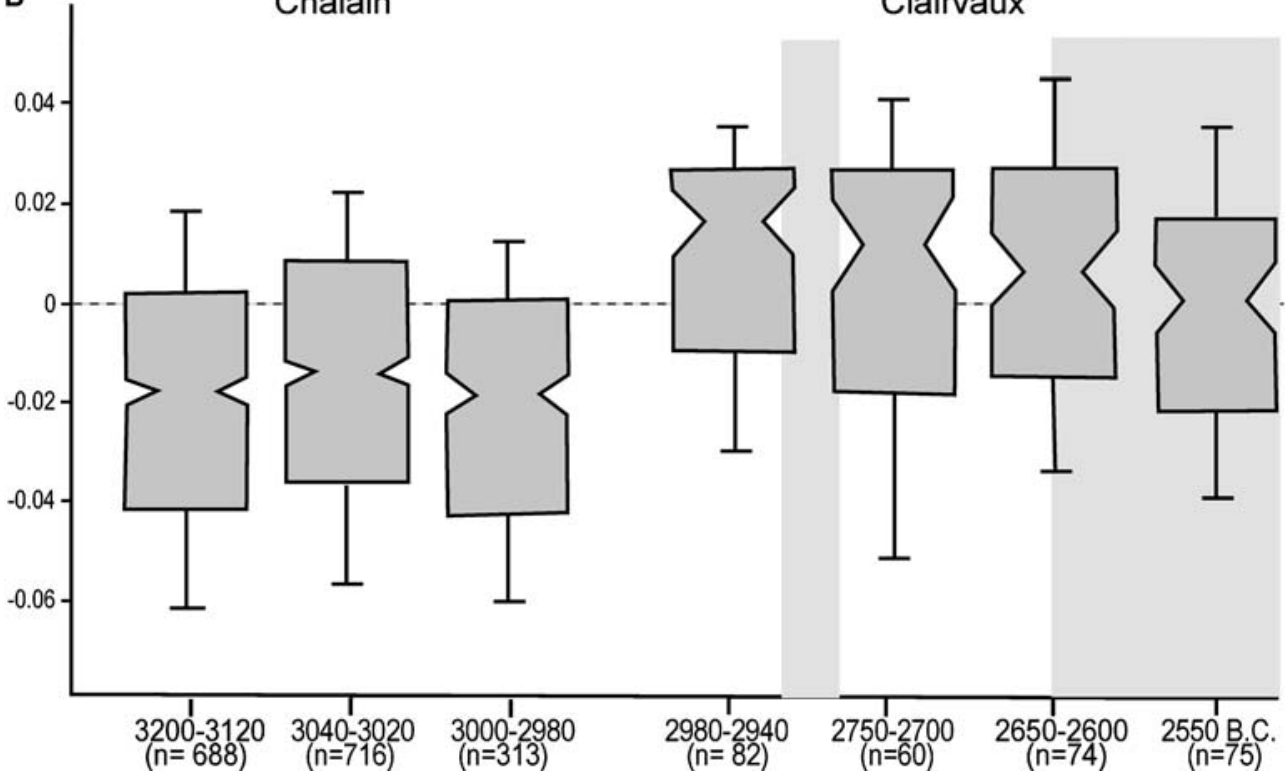


Fig. 8 LSI values of cattle bones in the Neolithic lakeshore settlements mentioned. A values from the Zürich area, after Hüster-Plogmann and Schibler 1997; B values from the lakes Chalain and Clairvaux in the French Jura (Arbogast unpubl.). In grey, phases with unfavourable climate conditions (after Fig. 2). The LSI values are based on the aurochs reference skeleton from the Danish settlement of Ullerslev (Steppan 2001). For further explanations, see text and legend of Fig. 7
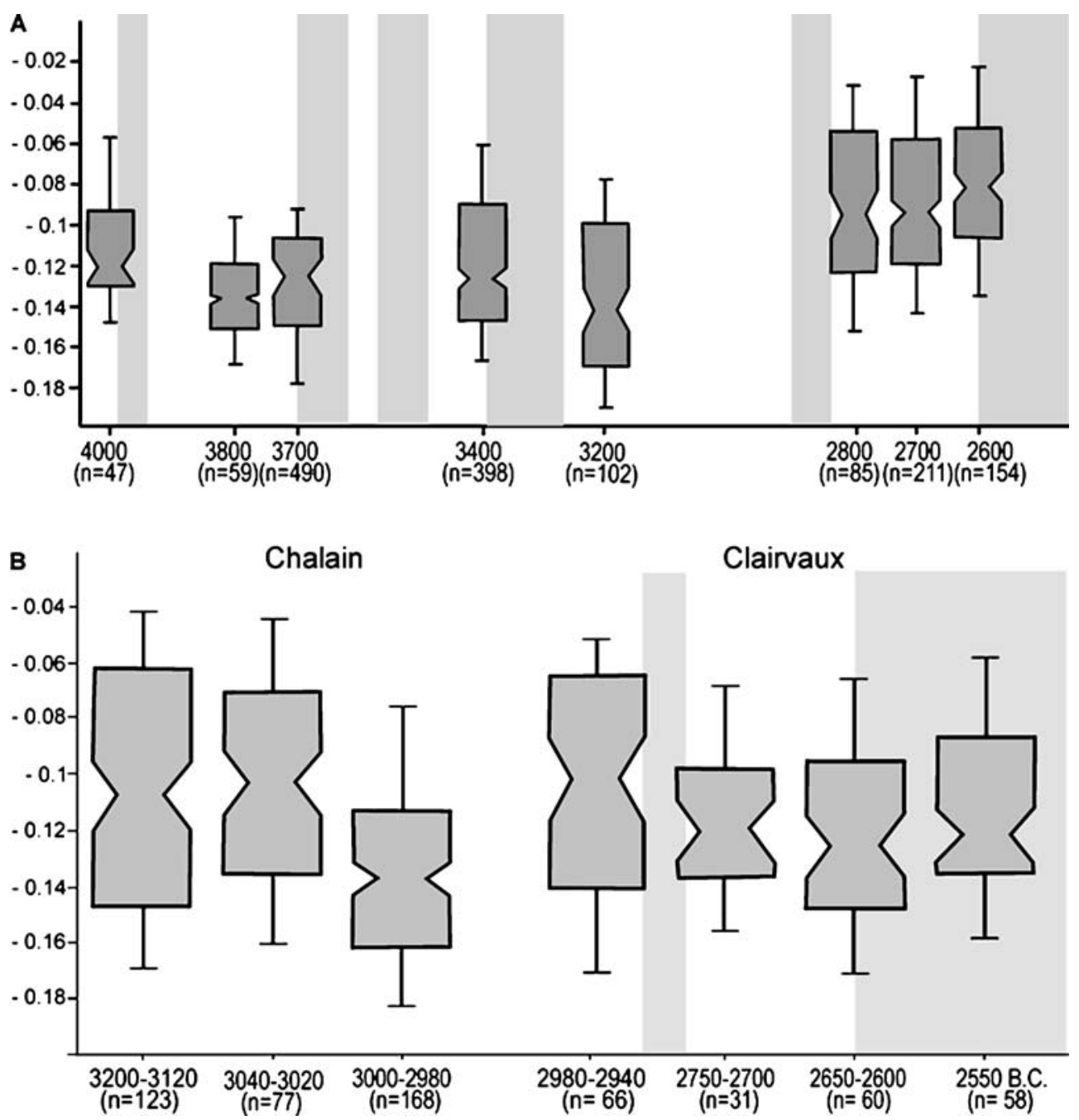

of Lac de Clairvaux (Fig. 7b). However, within one region (especially Lac de Clairvaux) a chronological fluctuation of the LSI values can also be recognized: they become smaller from 2600 B.C. onwards.

Concerning cattle bones, the highest mean LSI values for the eastern part of the Swiss Pre-Alps can be seen in the period 2800-2500 B.C. This includes all settlements of the Corded Ware (Schnurkeramik) culture at the end of the Neolithic lake dwelling sequence (Fig. 8a). In contrast, the smallest mean LSI values come from settlements of the Horgen culture around 3200 B.C. (Fig. 8a). During the beginning of the Horgen culture around 3400 B.C., at the settlement Arbon Bleiche 3 the cattle bones show a clearly higher mean LSI value. In the region of the French Jura lakes the cattle bones from the youngest phase of Lac de Chalain are clearly smaller than the bones from the oldest phase of Lac de Clairvaux (Fig. 8b). Both phases are dated to ca 3000 B.C.

\section{Discussion}

In the following discussion we will try to interrelate the results from sedimentology, historical sources and archaeobiology and to develop hypotheses about the possible causes of economic shifts during the time span 4300 2400 B.C. As shown in the results, part of the climatic deterioration concerns phases of wet and cold conditions during the spring and summer months. If we compare such phases with economically based data such as the importance of hunting we can observe some parallels, at least in the eastern part of the Swiss Pre-Alps. Here, a correlation between the great importance of bones from hunted animals and climatic deterioration phases can mostly be recognized (Figs. 2, 3 and 5). We interpret the great importance of hunting during phases of wet and cold climate as a reaction by the lakeshore dwelling farmers to climatically caused crop failures. The latter cannot be directly proven because quantification of on-site archaeobotanical data is not really possible. Also, the very weak signs of human impact in off-site pollen diagrams do not reflect such changes in an interpretable way. However, crop failures seem to be very probable, considering our knowledge of the historical sources. People obviously tried to compensate for lost calories by an intensification of hunting and surely also by collecting more wild plants and fruits (Schibler et al. 1997a, b; Hüster-Plogmann et al. 1999). Such scenarios are also known from indigenous populations in the North 
American woodlands (for citations, see the section on results). All in all, some of the shifts in animal bone proportions and "densities" point to a correlation between cold and wet climate phases and economic problems.

However, there is one period during the 32nd and 31st century B.C. which shows high percentages of up to $70 \%$ of bones of wild animals but no climatic deterioration connected with wet and cold springs and summers (Fig. 5). The same phenomenon can also be seen during the 31st century B.C. in the region of the French Jura lakes (Fig. 6). In the western part of the Swiss Pre-Alps we also find some high percentages of hunted animals during the period 3800-3700 B.C. when no signs of wet summers can be seen (Fig. 5). If we assume that increased reliance on hunting is not culturally determined but is an economically based reaction (Schibler 2004b, in press), we have to look for other reasons which might have influenced the production of food, especially crop production. Also, long periods of warm and dry conditions can have a negative influence on several aspects of husbandry, as known from historical sources. Therefore, drought periods may be the cause of the importance of hunting during the period $3200-3000$ в.с. or during the period 3800-3700 в.C. on the southern slopes of the western Jura mountains. The latter region is climatically favoured and drier than other regions in the Pre-Alps, and today it is a wine growing area.

Damage to cereal growth depends on the period of drought; plants are affected mostly in a younger developmental stage, during the formation of leaves and the differentiation of ears (Kappert and Rudorf 1959), which takes place during the spring months. However, in the very dry year or dry spring of 1540 , winter cereals were not damaged too seriously in Switzerland (C. Pfister, personal communication), but summer crops failed. Therefore, under such circumstances a part of the calories needed for staple food would be lacking.

There are, however, more possible reasons to explain an increase in using wild resources. Perhaps longer periods of intensive land use of a limited area, leading to an overexploitation of the soils, or plant diseases, could also lead to economic crises. Such a scenario can be shown at Chalain and Clairvaux because systematic research excavations were recently done there. Demographic growth is indirectly shown by the rise in the number of villages between 3180 and 2980 B.C. (Fig. 6; Pétrequin et al. 2005). This growth is marked by an increase in meat consumption which is based more on wild animals, especially red deer, than domesticated ones. It can be concluded that subsistence problems connected to population growth were solved by increasing the hunting (and probably also gathering) strategies rather than animal husbandry (Arbogast et al. 1996; Pétrequin et al. 1998, 2005). The mentioned problems possibly finally forced people to displace to the region of Lac de Clairvaux. Unfortunately, such a development cannot be shown in other parts of the lake-dwelling area because to a large extent in most of the regions there has been no systematic archaeological and archaeobiological research: our results are based mostly on materials from rescue excavations which were analysed to a lesser extent. Many more evaluations will have to be performed before we are able to give more precise answers to the observed economic shifts.

If we compare the metrical data on the red deer and the cattle bones according to the LSI values, it can be stated that, only for the red deer bones, some correlation with the importance of hunting and therefore in some areas with climatic deteriorations can be reconstructed. These are not direct correlations but are linked indirectly to the greater importance of hunting. During such phases the main goal was to produce as many calories as possible. Therefore big animals like older males or females were hunted. If the period of need of hunting took a longer time, younger animals were also hunted. This kind of hunting selection and pressure led in the end to a size reduction of red deer because the genetic influence of stronger animals was reduced. This is proven for the period between 3660 to 3600 B.C. at Zürichsee (Schibler et al. 1997a, b) where, during a period of 60 years, the red deer LSI values became smaller from the oldest (Zürich Mozartstrasse, layer 4u) to the youngest (Zürich Mozartstrasse, layer 4o) village (Schibler and Steppan 1999: Fig. 8). During this period of 60 years around 63 to $67 \%$ of the identifiable bones were of red deer. A similar explanation could also be true for the low red deer LSI values around 2800 B.C. (Fig. 7a).

Following this interpretation, the higher red deer LSI values at 3200-3000 and 2700-2500 B.C. would be the sign of less hunting pressure during a favourable climatic period for farming. But this is not fully true because we see some short periods even between 3200-3000 B.C. which show more hunting (Fig. 5). Possibly these periods were too short to have had an influence on animal size. This interpretation is assisted by the fact that the red deer LSI values of Arbon Bleiche 3, a settlement which existed for only 15 years (3384-3370 B.C.) are also not extremely low even if we have an importance of hunted animal bones of about $38 \%$ and red deer bones of $25 \%$ (Deschler-Erb and Marti-Grädel 2004).

The increased red deer hunting in the villages of the Lac de Chalain region during the period 3100-3000 B.C. shows that there may have been some economic problems. Also there, hunting selection obviously led to a reduction in the size of red deer (Fig. 7b). In the somewhat later villages of the Lac de Clairvaux region, where hunting was not so important, the LSI values are clearly higher (Fig. 7b). Only in the latest phase, around 2550 B.C. during which hunting was concentrated on red deer (Arbogast and Pétrequin 1993, Fig. 3) do the LSI values of the red deer bones decrease (Fig. 7b). For this phenomenon the same reasons (overpopulation and overexploitation) may be responsible, as already stated above.

No climatic influence can be traced from the biometrical data of the cattle bones. According to the LSI values, the smallest cattle bones are found in the Horgen culture villages during the period 3200-3100 B.C. in the region of the eastern Pre-Alps (Fig. 8a). Similar small LSI values can also be seen at Lac de Chalain around 3000 B.C. (Fig. 8b). Small cattle bones are also known from several Horgen culture villages around Bielersee (HüsterPlogmann and Schibler 1997). These smaller and more 
robust cattle and the broader biometrical amplitude are possibly due to the use of cattle as draught animals (HüsterPlogmann and Schibler 1997). During the Horgen culture there are several lines of evidence for this for the first time (Pétrequin et al. in press). If the farmers of the Horgen culture began to use at least some male and female cattle at a younger age as draught animals, reduced growth could be a possible reaction. This is perhaps the reason that compared to the older phases, during the Horgen culture in addition to "normal-sized" cattle, more smaller animals were present. Therefore the size variability, especially in the smaller LSI range increases (Fig. 8a).

Why the LSI values for the cattle bones from the villages of the period 2800-2500 B.C. in the eastern Pre-Alps are clearly higher compared to those from earlier villages or from the villages of the same period in the Lac de Clairvaux region is not yet known (Fig. 8). Future research must show if this is due to an influence of new cattle breeds which were introduced together with the cultural influence of the Corded Ware culture.

Even when only part of the observed variations in hunting and collecting are due to climatic influence can we conclude that economic shifts during the Neolithic period were primarily caused by food shortages, and were not culturally determined. Climatic fluctuations are obviously important reasons for famines. In many of the observed cases this means colder and wetter conditions during the summer months, although warmer and very dry climatic conditions could also have caused famines. However, the combination of data from several regions shows that other factors must also be envisaged as causes of food shortages. So, for instance, local overexploitation of a settlement area or cereal diseases could be responsible factors. During such periods of scarcity, red deer hunting would have become more important, and mainly stronger red deer were shot. This selection finally - after some decades - led to the situation in which only smaller animals were present in an area.

To recognize the mentioned changes in the economy, including shifts in animal sizes, it is essential to date the investigated material to periods which are at most a few decades long. A lesser precision of dating can lead to a mixture of results coming from favourable and unfavourable periods. This means that the extraordinarily good preservation of the Neolithic lake dwellings, together with the possibility of precise dendrochronological dating is one of the most powerful instruments with which the relationship between climate, economy, environment and human culture can be highlighted. Therefore, we have to continue with archaeobiological and palaeoecological research in this area in order to be able to contribute one day to a more clear-cut interpretation of the existing economic shifts. In addition, the results of off-site pollen data have to be included in our considerations.

Acknowledgements This study is dedicated to Brigitta Ammann as a memory of our fruitful collaboration, which began during the evaluation of the lake dwellings at Twann around 1980. We wish her many fruitful years dedicated to scientific work, without the burdens of administration and teaching.
Financial support for this study was from the French CNRS (Program ECLIPSE), from the European program ACCROTELM, Swiss National Foundation for Scientific Research (SNF), many Swiss Cantonal Archaeological Offices and Basel University. C. Pfister (Institute of History, Bern University) provided useful information about historical sources. Finally, we thank the guest editor (Pim van der Knaap) and one unknown reviewer for some very valuable comments and suggestions, and J. Greig for improving the English.

\section{References}

Ammann B (1989) Late-Quaternary palynology at Lobsigensee. Regional vegetation history and local lake development. Diss Bot 137:1-157

Ammann B, Bollinger T, Jacomet S, Liese-Kleiber H, Piening U (1981) Botanische Untersuchungen. (Die neolithischen Ufersiedlungen von Twann 14). Staatlicher Lehrmittelverlag, Bern

Arbogast R-M (1997) La grande faune de Chalain 3. In: Pétrequin $\mathrm{P}$ (ed) Les sites littoraux néolithiques de Clairvaux-Les-Lacs et de Chalain (Jura), vol III, Chalain station 3, 3200-2900 av. J.-C. (Editions de la Maisons des Sciences de l'Homme, Paris, vol 2), pp 641-691

Arbogast R-M, Magny M, Pétrequin P (1995) Expansions et déprises agricoles au Néolithique: populations, cultures céréalières et climat dans la combe d'Ain (Jura) de 3700 à 2500 av. J.-C. In: L'homme et la dégradation de l'environnement. XVèmes Rencontres Internationales d'Archéologie et d'Histoire d'Antibes, Juan-les-Pins. Edition APCDA, pp 20-41

Arbogast R-M, Magny M, Pétrequin P (1996) Climat, cultures céréalières et densité de population au Néolithique: le cas des lacs du Jura français de 3500 à 2500 av. J.C. Archäologisches Korrespondenzblatt 6:121-144

Arbogast R-M, Pétrequin P (1993) La chasse du cerf au Néolithique dans le Jura: gestion d'une population animale sauvage. In: Exploitation des animaux sauvages à travers le temps. XIII ${ }^{\circ}$ rencontres Internationales d'Archéologie et d'Histoire d'Antibes, $\mathrm{IV}^{\circ}$ colloque international de l'Homme et l'Animal, Société de Recherche Interdisciplinaire, Ed. APDCA, Juan-Les-Pins, pp 221-232

Beckmann M (2004) Pollenanalytische Untersuchungen der Zeit der Jäger und Sammler und der ersten Bauern an zwei Lokalitäten des Zentralen Schweizer Mittellandes. Umwelt und erste Eingriffe des Menschen in die Vegetation vom Paläolithikum bis zum Jungneolithikum. (Diss Bot 390). Cramer, Berlin, Stuttgart

Beer J (2000) Long-term indirect indices of solar variability. Space Sci Rev 11:53-66

Blaauw M, Geel B van, Plicht J van der (2004) Solar forcing of climate change during the mid-Holocene: indications from raised bogs in the Netherlands. The Holocene 14:35-44

Bogaard A (2004) Neolithic farming in central Europe. An archaeobotanical study of crop husbandry practices. Routledge, London

Bond G, Kromer B, Beer J, Muscheler R, Evans MN, Showers W, Hoffmann S, Lotti-Bond R, Hajdas I, Bonani G (2001) Persistent solar influence on North Atlantic climate during the Holocene. Science 294:2130-2136

Bortenschlager S (1970) Waldgrenz- und Klimaschwankungen im pollenanalytischen Bild des Gurgler Rotmoos. Mitteilungen der Ostalpin-Dinarischen Gesellschaft für Vegetationskunde 11:19_ 26

Bortenschlager S (1977) Ursachen and Ausmass postglazialer Waldgrenzschwankungen in den Ostalpen. In: Frenzel B (ed) Dendrochronologie und postglaziale Klimaschwankungen in Europa. Steiner, Wiesbaden, pp 260-266

Brombacher C, Jacomet S (1997) Ackerbau, Sammelwirtschaft und Umwelt: Ergebnisse archäobotanischer Untersuchungen. In: Schibler J, Hüster-Plogmann H, Jacomet S, Brombacher C, Gross-Klee E, Rest-Eicher A (eds) Ökonomie und Ökologie neolithischer und bronzezeitlicher Ufersiedlungen am Zürichsee. 
Ergebnisse der Ausgrabungen Mozartstrasse, Kanalisationssanierungen Seefeld, AKAD/Pressehaus und Mythenschloss in Zürich. Monographien der Kantonsarchäologie Zürich 20. Zürich and Egg, pp 220-279

Chambers FM, Ogle MI, Blackford JJ (1999) Palaeoenvironmental evidence for solar forcing of Holocene climate: linkages to solar science. Prog Phys Geogr 23:181-204

Deschler-Erb S, Marti-Grädel E (2004) Viehhaltung und Jagd. Ergebnisse der Untersuchung der handaufgelesenen Tierknochen. In: Jacomet S, Schibler J, Leuzinger U. (eds) Die jungsteinzeitliche Seeufersiedlung Arbon-Bleiche 3: Umwelt und Wirtschaft. Archäologie im Thurgau 12, Frauenfeld, pp 158-252

Digerfeldt G (1988) Reconstruction and regional correlation of Holocene lake-level fluctuations in lake Bysjön, South Sweden. Boreas 17:165-182

Digerfeldt G, Olsson S, Sandgren P (2000) Reconstruction of lakelevel changes in lake Xinias, central Greece, during the last 40000 years. Palaeogeogr Palaeoclimatol Palaeoecol 158:6582

Flannery KV (1986) Guila Naquitz. Archaic foraging and early agriculture in Oaxaca, Mexico. Academic Press, New York

Gaillard M-J (1985) Postglacial palaeoclimatic changes in Scandinavia and Central Europe. A tentative correlation based on studies of lake-level fluctuations. Ecol Mediterr 11:159175

Gläser R, Brazdil R, Pfister C, Dobrovolny P, Barriendos Valve M, Bokwa A, Camuffo D, Kotyza O, Limanowka D, Racz L, Rodrigo FS (1999) Seasonal temperature and precipitation fluctuations in selected parts of Europe during the sixteenth century. Clim Change 43:169-200

von Grafenstein U, Erlenkeuser H, Müller J, Jouzel J, Johnsen S (1998) The cold event 8200 years ago documented in oxygen isotope records of precipitation in Europe and Greenland. Clim Dyn 14:73-81

Gross E, Jacomet S, Schibler J (1990) Stand und Ziele der wirtschaftsarchäologischen Forschung an neolithischen Ufer- und Inselsiedlungen im Unteren Zürichseeraum (Kt. Zürich, Schweiz). In: Schibler J, Sedlmeier J, Spycher H (eds) Festschrift für Hans R. Stampfli. Beiträge zur Archäozoologie, Archäologie, Anthropologie, Geologie und Paläontologie. Helbing und Lichtenhahn, Basel, pp 77-100

Gross-Klee E, Maise Ch (1997) Sonne, Vulkane und Seeufersiedlungen. Jahrbuch der Schweizerischen Gesellschaft für Ur- und Frühgeschichte 80:5-94

Guiot J, Harrison SP, Prentice IC (1993) Reconstruction of Holocene pattern of moisture in Europe using pollen and lake-level data. Quat Res 40:139-149

Haas JN, Richoz I, Tinner W, Wick L (1998) Synchronous Holocene climatic oscillations recorded on the Swiss Plateau and at the timberline in the Alps. Holocene 8:301-304

Haas JN, Magny M (2004) Die jungsteinzeitliche Besiedlung von Arbon-Bleiche 3 im Rahmen der abrupten, globalen Klimaschwankungen vor 5600-5000 Jahren. In: Jacomet S, Schibler J, Leuzinger U (eds) Die jungsteinzeitliche Seeufersiedlung Arbon-Bleiche 3: Umwelt und Wirtschaft. Archäologie im Thurgau 12, Frauenfeld, pp 41-49

Hadorn P (1994) Saint-Blaise/Bains des Dames 1, Palynologie d'un site Néolithique et histoire de la végétation des derniers 16000 ans. Archéologie Neuchâteloise 18. Musée Cantonal d'Archéologie, Neuchâtel

Hammett JE (1997) Interregional pattern of land use and plant management in native North America. In: Gremillion KJ (ed) People, plants and landscapes. Studies in Palaeoethnobotany. University of Alabama Press Tuscaloosa and London, pp 195-216

Harrisson SP, Digerfeldt G (1993) European lakes as palaeohydrological and palaeoclimatic indicators. Quat Sci Rev 12:233248

Harrisson SP, Yu G, Tarasov PE (1996) Late Quaternary lake-level record from Northern Eurasia. Quat Res 45:138-159

Heiri O, Lotter AF, Hausmann S, Kienast F (2003) A chironomidbased Holocene summer air temperature reconstruction from the Swiss Alps. Holocene 13:477-484
Heiri O, Tinner W, Lotter AF (2004) Evidence for cooler European summers during periods of changing meltwater flux to the North Atlantic. PNAS 101:15285-15288

Hosch S, Jacomet S (2004) Ackerbau und Sammelwirtschaft. Ergebnisse der Untersuchung von Samen und Früchten. In: Jacomet S, Leuzinger U, Schibler J (eds) Die jungsteinzeitliche Seeufersiedlung Arbon Bleiche 3. Umwelt und Wirtschaft. Archäologie im Thurgau 12. Frauenfeld, pp 112-157

Hosch S, Zibulski P (2003) The influence of inconsistent wet-sieving procedures on the macroremain concentration in waterlogged sediments. J Archaeol Sci 30:849-857

Hüster-Plogmann H (2004) Fischfang und Kleintierbeute. Ergebnisse der Untersuchung von Tierresten aus den Schlämmproben. In: Jacomet S, Leuzinger U, Schibler J (eds) Die jungsteinzeitliche Seeufersiedlung Arbon Bleiche 3. Umwelt und Wirtschaft. Archäologie im Thurgau 12, Frauenfeld, pp 253-276

Hüster-Plogmann H, Schibler J (1997) Archäozoologie. In: Schibler J, Hüster-Plogmann H, Jacomet S, Brombacher C, GrossKlee E, Rast-Eicher A (eds) Ökonomie und Ökologie neolithischer und bronzezeitlicher Ufersiedlungen am Zürichsee. Ergebnisse der Ausgrabungen Mozartstrasse, Kanalisationssanierungen Seefeld, AKAD/Pressehaus und Mythenschloss in Zürich. Monographien Kantonsarchäologie Zürich 20. Zürich and Egg, pp 40-121

Hüster-Plogmann H, Schibler J, Jacomet S (1999) The significance of aurochs as hunted animal in the Swiss Neolithic. In: Weniger G-C (ed) Archäologie und Biologie des Auerochsen. Wissenschaftliche Schriften des Neanderthalmuseums 1, Neanderthalmuseum Mettmann, pp 151-160

Jacomet S (2004) Archaeobotany. A vital tool in the investigation of lake-dwellings. In: Menotti F (ed) Living on the lake in prehistoric Europe. 150 years of lake-dwelling research. Routledge, London, pp 162-177

Jacomet S (2006) Plant economy in the northern Alpine lake dwelling area - 3500-2400 B.C. cal. In: Karg S, Baumeister R, Schlichtherle H, Robinson DE (eds) Economic and environmental changes during the 4th and 3rd Millennia B.C. Proceedings of the 25th Symposium of the AEA, Sept. 2004 in Bad Buchau, Germany. Environmental Archaeology 11:64-83

Jacomet $\mathrm{S}$ (in press) Neolithic plant economies in the northern alpine foreland (Central Europe) from 5500-3500 B.C. cal. In: Colledge $\mathrm{S}$, Conolly J (eds) Archaeobotanical perspectives on the origin and spread of agriculture in southwest Asia and Europe. London

Jacomet S, Brombacher C (2005) Reconstructing intra-site patterns in Neolithic lakeshore settlements: the state of archaeobotanical research and future prospects. In: Della Casa P, Trachsel M (eds) WES'04 - Wetland Economies and Societies. Proceedings of the International Conference in Zurich, 10 13 March 2004 (Collectio Archaeologica 10), Zürich, pp 6994

Jacomet S, Brombacher C, Dick M (1989) Archäobotanik am Zürichsee. Ackerbau, Sammelwirtschaft und Umwelt von neolithischen und bronzezeitlichen Seeufersiedlungen im Raum Zürich. Ergebnisse von Untersuchungen pflanzlicher Makroreste der Jahre 1979-1988. Züricher Denkmalpflege, Monographien 7, Orell Füssli, Zürich

Jacomet S, Leuzinger U, Schibler J (eds) (2004) Die jungsteinzeitliche Seeufersiedlung Arbon Bleiche 3. Umwelt und Wirtschaft. Archäologie im Thurgau 12, Frauenfeld

Jacomet S, Schibler J (1985) Die Nahrungsversorgung eines jungsteinzeitlichen Pfynerdorfes am unteren Zürichsee. Archäologie der Schweiz 8:125-141

Kappert H, Rudorf W (1959) Handbuch der Pflanzenzüchtung II: Züchtung der Getreidearten. Parey, Hamburg and Berlin

Liese-Kleiber H (1993) Settlement and landscape history at the Federsee, south-west Germany, as reflected in pollen diagrams. Veget Hist Archaeobot 2:37-46

Lundström-Baudais K (1986) Étude paléoethnobotanique de la station III de Clairvaux. In: Pétrequin P (ed) Les sites littoraux néolithiques de Clairvaux-Les-Lacs (Jura) I. Problématique générale. L'exemple de la Station 3. Editions de la Maison des Sciences de l'Homme, Paris, pp 311-404 
Luterbacher J, Rickli R, Xoplaki E, Tinguely C, Beck C, Pfister C, Wanner H (2001) The Late Maunder Minimum (1675-1715) - A key period for studying decadal scale climatic change in Europe. Clim Change 49:441-462

Magny M (1992) Holocene lake-level fluctuations in Jura and the northern subalpine ranges, France: regional pattern and climatic implications. Boreas 21:319-334

Magny M (1993a) Solar influences on Holocene climatic changes illustrated by correlations between past lake-level fluctuations and the atmospheric ${ }^{14} \mathrm{C}$ record. Quat Res 40:1-9

Magny M (1993b) Holocene fluctuations of lake levels in the French Jura and Subalpine ranges and their implications for past general circulation pattern. Holocene 3:306-313

Magny M (1993c) Climatic contribution can provide an answer for prehistoric lake-dwellings. Compte-Rendus Académie des Sciences Paris 316:1619-1625

Magny M (1998) Reconstruction of Holocene lake-level changes in the Jura (France): methods and results. Paläoklimaforschung 25:67-85

Magny M (2004) Holocene climate variability as reflected by midEuropean lake-level fluctuations and its probable impact on prehistoric human settlements. Quat Int 113:65-79

Magny M (in press) L'histoire du niveau du lac et du climat à Chalain (Jura, France) de 3300 à 2000 cal B.c. à partir des séquences stratigraphiques des stations 4 et 19. In: Pétrequin P (ed) Les sites littoraux néolithiques de Clairvaux et de Chalain, vol 4. Editions de la Maison des Sciences de l'Homme, Paris

Magny M, Guiot J, Schoellammer P (2001) Quantitative reconstruction of Younger Dryas to mid-Holocene palaeoclimates at Le Locle, Swiss Jura, using pollen and lake-level data. Quat Res 56:170-180

Magny M, Bégeot C, Guiot J, Marguet A, Billaud Y (2003) Reconstruction and palaeoclimatic interpretation of mid-Holocene vegetation and lake-level changes at Saint-Jorioz, lake Annecy, French Pre-Alps. Holocene 13:265-275

Magny M, Haas JN (2004) A major widespread climatic change around $5300 \mathrm{cal}$. yr B.P. at the time of the Alpine Iceman. J Quat Sci 19:423-430

Magny M., Peyron O, Bégeot C, Guiot J (2005) Quantitative reconstruction of mid-Holocene climatic variations in the northern Subalpine zone. A comparative study of two sites from lakes Morat (Swiss Plateau) and Annecy (French Pre-Alps). Boreas 34:434-444

Magny M, Leuzinger U, Bortenschlager S, Haas JN (2006) Tripartite climate reversal in Central Europe 5600-5300 years ago. Quat Res 65:3-19

Maier U (1996) Morphological studies of free-threshing wheat ears from a Neolithic site in southwest Germany, and the history of the naked wheats. Veget Hist Archaeobot 5:39-55

Maier U (2001) Archäobotanische Untersuchungen in der neolithischer Ufersiedlung Hornstaad-Hörnle IA am Bodensee. In: Maier U, Vogt R (eds) Siedlungsarchäologie im Alpenvorland VI. Botanische und pedologische Untersuchungen zur Ufersiedlung Hornstaad-Hörnle IA. Forschungen und Berichte zur Vorund Frühgeschichte in Baden-Württemberg 74, Theiss, Stuttgart, pp 9-384

Mayewski PA, Rohling EE, Stager JC, Karlén W, Maasch KA, Meeker LD, Meyerson EA, Gasse F, van Kreveld S, Holmgren K, Lee-Thorp J, Rosqvist J, Rack F, Staubwasser M, Schneider R, Steig E (2004) Holocene climate variability. Quat Res 62:243-255

Meadow RH (1999) The use of size index scaling techniques for research on archaeozoological collections from the Middle East. In: Becker C et al. (eds) Festschrift A. von den Driesch, Historia Animalium ex Ossibus. Beiträge zur Paläoanatomie, Archäologie, Ägyptologie, Ethnologie und Geschichte der Tiermedizin. Internationale Archäologie, Studia Honoraria 8, Leidorf, Rahden/Westfalen, pp 285-300

Mermod O (2000) Die endneolithische Seeufersiedlung SaintBlaise/Bains des Dames NE. Botanische Untersuchungen zur Vegetation, Landwirtschaft und Ernährung in der Auvernier Cordé Kultur (2640-2450 B.C.). Doctoral Thesis No 13705, ETH, Zürich
Messerli B, Grosjean M, Hofer T, Nunez L, Pfister C (2000) From nature-dominated to human-dominated environmental changes. Quat Sci Rev 19:459-479

Muscheler R, Beer J, Wagner G, Finkel RC (2000) Changes in deep-water formation during the Younger Dryas event inferred from ${ }^{10} \mathrm{Be}$ and ${ }^{14} \mathrm{C}$ records. Nature 408:567-570

Patzelt G (1977) Der zeitliche Ablauf und das Ausmass postglazialer Klimaschwankungen in den Alpen. In: Frenzel B (ed) Dendrochronologie und postglaziale Klimaschwankungen in Europa. Steiner, Wiesbaden, pp 248-259

Payne S, Bull G (1988) Components of variation in measurements of pig bones and teeth, and the use of measurements to distinguish wild from domestic pig remains. Archaeozoologia II/1, 2:27-66

Pétrequin P (ed) (1997) Les sites littoraux néolithiques de ClairvauxLes-Lacs et de Chalain (Jura) III. Chalain station 3, 3200-2900 av. J.-C. (Editions de la Maison des Sciences de l'Homme), Paris. vols $1-2$

Pétrequin P, Arbogast R-M, Bourquin-Mignot C, Lavier C, Viellet A (1998) Demographic growth, environmental changes and technical adaptations: responses of an agricultural community from the 32nd to 30th centuries cal B.C. World Archaeol 30: 181-192

Pétrequin P, Arbogast R-M, Pétrequin A-M, van Willigen S, Bailly, M (eds) (in press) Premiers chariots, premiers araires. La traction animale en Europe au IVe millénaire avant notre ère. Editions du CNRS, Valbonne

Pétrequin P, Magny M, Bailly M (2005) Habitat lacustre, densité de population et climat. L'exemple du Jura français. In: Della Casa P, Trachsel M (eds) WES'04 - Wetland economies and societies. Proceedings of the International Conference in Zurich, 10-13 March 2004 Collectio Archaeologica 10, Zürich, pp 143-168

Pfister C (1985) Bevölkerung, Klima und Agrarmodernisierung 1525-1860. Das Klima der Schweiz von 1525-1860 und seine Bedeutung in der Geschichte von Bevölkerung und Landwirtschaft I and II. Academica Helvetica 6/1 and 2. Haupt, Bern

Pfister C (2001) Klimawandel in der Geschichte Europas. Zur Entwicklung und zum Potenzial der historischen Klimatologie. Österreichische Zeitschrift für Geschichtswissenschaften 12/2:7-42

Pfister C, Brazdil R, Glaser R (eds) (1999) Climatic variability in sixteenth century Europe and its social dimension. Clim Change 43

Renssen H, van Geel B, van der Plicht J, Magny M (2000) Reduced solar activity as a trigger for the start of the Younger Dryas? Quat Int 68-71:373-383

Richoz I, Haas J-N (1995) Flora und Vegetation im Schweizer Mittelland und im Jura. In: Stöckli WE, Niffeler U, Gross-Klee E (eds) Neolithikum. Die Schweiz vom Paläolithikum bis zum frühen Mittelalter SPM vol 2, Verlag Schweizerische Gesellschaft für Ur- und Frühgeschichte, Basel, pp 59-72

Rösch M (1990) Vegetationsgeschichtliche Untersuchungen im Durchenbergried. In: Siedlungsarchäologie im Alpenvorland II. Forschungen und Berichte zur Vor- und Frühgeschichte in Baden-Württemberg 37:9-64

Rösch M (1992) Human impact as registered in pollen record: some results from the western Lake Constance region, Southern Germany. Veget Hist Archaeobot 1:101-109

Rösch M (1993) Prehistoric land use as recorded in a lake-shore core at Lake Constance. Veget Hist Archaeobot 2:213-232

Rösch M (1997) Botanische Hinweise zur Besiedlungsdichte im Bodenseebecken zwischen 3000 und 500 v. Chr. In: Rittershofer K-F (ed) Demographie der Bronzezeit. Paläodemographie Möglichkeiten und Grenzen. Internationale Archäologie 36: 5 13

Rösch M (2000) Anthropogener Landschaftswandel in Mitteleuropa während des Neolithikums. Beobachtungen und Überlegungen zu Verlauf und möglichen Ursachen. Germania 78:293-318

Schibler J (2004a) Bones as a key for reconstruon and economy of the lake-dwelling societies. In: Menotti F (ed) Living on the lake in prehistoric Europe. 150 years of lake-dwelling research. Routledge, London, pp 144 161 
Schibler J (2004b) Kurzfristige Klimaschwankungen aufgrund archäologischer Daten und ihre Auswirkungen auf die prähistorischen Gesellschaften. In: Gamerith W, Messerli P, Meusburger P, Wanner H (eds) Alpenwelt - Gebirgswelten. Inseln, Brücken, Grenzen. Tagungsbericht und wissenschaftliche Abhandlungen, 54. Deutscher Geographentag Bern, 28. September bis 4. Oktober 2003. Heidelberg Bern, pp 87-93

Schibler $\mathrm{J}$ (in press) Economy and environment of the 4th and 3rd millenium cal B.C. in the area of the northern alpine foreland based on animal bones. In: Karg S, Schlichtherle H, Baumeister $\mathrm{R}$ (eds) Economic and environmental changes during the 4th and 3rd Millennia B.C. Proceedings of the 25th Symposium of the AEA, Sept. 2004 in Bad Buchau, Germany. Environmental Archaeology 11:47-62

Schibler J, Chaix L (1995) Wirtschaftliche Entwicklung aufgrund archäozoologischer Daten / L'évolution économique sur la base de données archéozoologiques. In: Stöckli WE, Niffeler U, Gross-Klee E (eds) Die Schweiz vom Paläolithikum bis zum frühen Mittelalter SPM vol 2: Neolithikum. Verlag Schweizerische Gesellschaft für Ur- und Frühgeschichte, Basel, pp 97120

Schibler J, Hüster-Plogmann H (1995) Die neolithische Wildtierfauna und ihr Aussagegehalt betreffend Umwelt und Umweltveränderungen/La faune sauvage néolithique: recontruction de l'environnement et des transformations environnementales. In: Die Schweiz vom Paläolithikum bis zum frühen Mittelalter 2: Neolithikum. Verlag Schweizerische Gesellschaft für Ur- und Frühgeschichte, Basel, pp 76-83

Schibler J, Steppan K (1999) Human impact on the habitat of large herbivores in eastern Switzerland and southwest Germany in the Neolithic. Archeofauna 8:87-99

Schibler J, Jacomet S (1999) Archaeozoological and archaeobotanical evidence of human impact on Neolithic environments in Switzerland. In: Benecke N (ed) The Holocene history of the European vertebrate fauna-Modern aspects of research. Archäologie in Eurasien 6, Leidorf, Rahden/Westfalen, pp 339354

Schibler J, Hüster-Plogmann H, Jacomet S, Brombacher Ch, GrossKlee E, Rast-Eicher A (1997a) Ökonomie und Ökologie neolithischer und bronzezeitlicher Ufersiedlungen am Zürichsee. Ergebnisse der Ausgrabungen Mozartstrasse, Kanalisationssanierung Seefeld, AKAD/Pressehaus und Mythenschloss in Zürich. (Monographien der Kantonsarchäologie Zürich 20), Zürich
Schibler J, Jacomet S, Hüster-Plogmann H, Brombacher C (1997b) Economic crash in the 37th and 36th centuries cal. B.C. in Neolithic lake shore sites in Switzerland. Anthropozoologica 25/26:553-570

Schmidt B, Gruhle W (2003) Niederschlagsschwankungen in Westeuropa während der letzten 8000 Jahre. Versuch einer Rekonstruktion mit Hilfe eines neuen dendrochronologischen Verfahrens (Grad der Wuchshomogenität). Archäologisches Korrespondenzblatt 33:281-300

Steig EJ (1999) Mid-Holocene climate change. Science 286:14851487

Steppan K (2001) Ur oder Hausrind ? Die Variabilität der Wildtieranteile in linearbandkeramischen Tierknochenkomplexen. In: Arbogast R-M, Jeunesse C, Schibler J (eds) Rôle et statut de la chasse dans le Néolithique ancien danubien (5500-4900 av. J.-C.). Premières Rencontres Danubiennes. Actes de la première Table-Ronde, Strasbourg 20-21 nov. 1996, pp 171-188

Stöckli WE, Niffeler U, Gross-Klee E (1995) Die Schweiz vom Paläolithikum bis zum frühen Mittelalter SPM 2: Neolithikum. Schweizerische Gesellschaft für Ur- und Frühgeschichte, Basel

Stuiver M, Reimer PJ, Bard E, Beck JW, Burr GS, Hughen KA, Kromer B, McCormac G, Plicht J van der, Spurk M (1998) Intcal98 radiocarbon age calibration, 24 000-0 cal B.P. Radiocarbon 40:1041-1083

Tinner W, Theurillat JP (2003) Uppermost limit, extent, and fluctuations of the timberline and treeline ecocline in the Swiss Central Alps during the past 11500 years. Arctic Antarctic Alpine Res 35:18-169

Uerpmann H-P (1979) Probleme der Neolithisierung des Mittelmeerraums. Beihefte zum Tübinger Atlas des Vorderen Orients 28, Tübingen

Uerpmann H-P (1990) Die Domestikation des Pferdes im Chalkolithikum West-und Mitteleuropas. Madrider Mitteilungen 31:109-153

Zoller H (1977) Alter und Ausmass postglazialer Klimaschwankungen in den Schweizer Alpen. In: Frenzel B (ed) Dendrochronologie und postglaziale Klimaschwankungen in Europa. Steiner, Wiesbaden, pp 271-281 